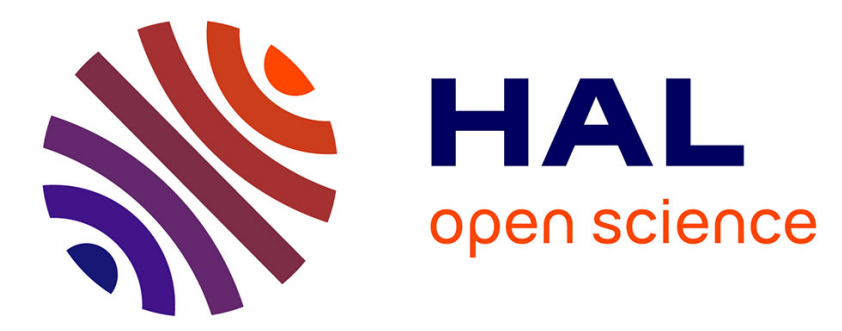

\title{
Inverse analysis of the planktonic food web dynamics related to phytoplankton bloom development on the continental shelf of the Bay of Biscay, French coast
}

E Marquis, N Niquil, D Delmas, Hj. Hartmann, D. Bonnet, F Carlotti, A. Herbland, C. Labry, B. Sautour, P. Laborde, et al.

\section{To cite this version:}

E Marquis, N Niquil, D Delmas, Hj. Hartmann, D. Bonnet, et al.. Inverse analysis of the planktonic food web dynamics related to phytoplankton bloom development on the continental shelf of the Bay of Biscay, French coast. Estuarine, Coastal and Shelf Science, 2007, 10.1016/j.ecss.2007.01.003 . hal01248037

\section{HAL Id: hal-01248037 \\ https://hal.science/hal-01248037}

Submitted on 26 Dec 2016

HAL is a multi-disciplinary open access archive for the deposit and dissemination of scientific research documents, whether they are published or not. The documents may come from teaching and research institutions in France or abroad, or from public or private research centers.
L'archive ouverte pluridisciplinaire HAL, est destinée au dépôt et à la diffusion de documents scientifiques de niveau recherche, publiés ou non, émanant des établissements d'enseignement et de recherche français ou étrangers, des laboratoires publics ou privés. 


\title{
Inverse analysis of the planktonic food web dynamics related to phytoplankton bloom development on the continental shelf of the Bay of Biscay, French coast
}

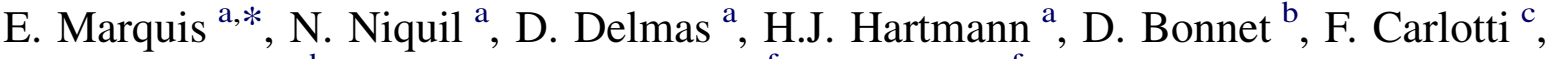 \\ A. Herbland ${ }^{\text {d }}$, C. Labry ${ }^{\mathrm{e}}$, B. Sautour ${ }^{\mathrm{f}}$, P. Laborde ${ }^{\mathrm{f}}$, A. Vézina ${ }^{\mathrm{g}}$, C. Dupuy ${ }^{\mathrm{a}}$ \\ ${ }^{a}$ Centre de Recherche sur les Environnements Littoraux et Anthropisés, CNRS-IFREMER-ULR UMR 6217, Université de La Rochelle, \\ Pôle Sciences et Technologie, avenue Michel Crépeau 17042 La Rochelle, France \\ ${ }^{\mathrm{b}}$ Ecosystèmes Lagunaires, UMR 5119, CNRS-Université Montpellier II, Place Eugène Bataillon, 34095 Montpellier Cedex 05, France \\ ${ }^{\mathrm{c}}$ Unité Mixte de Recherche 6535, CNRS Université de la Méditerranée, Observatoire des Sciences de l'Univers (OSU), Centre d'Océanologie de Marseille \\ (COM), Rue de la Batterie des lions, 13007 Marseille, France \\ ${ }^{\mathrm{d}}$ IFREMER Calédonie, DAC, B.P. 2059, 98800 Nouméa, Nouvelle-Calédonie, France \\ ${ }^{\mathrm{e}}$ IFREMER/Centre de Brest, DYNECO, Laboratoire Pelagos, BP 70, 29280 Plouzané, France \\ ${ }^{\mathrm{f}}$ Laboratoire d'Océanographie Biologique, UMR CNRS 5805 "EPOC', Université Bordeaux I, 2 rue du Professeur Jolyet, 33120 Arcachon, France \\ ${ }^{\mathrm{g}}$ Bedford Oceanographic Institute, Promenade Challenger, Dartmouth B2Y 4A2, Canada
}

Received 4 October 2006; accepted 4 January 2007

Available online 1 March 2007

\begin{abstract}
Along the French coast of the Bay of Biscay, the seasonal progression of phytoplankton presents specific hydrographic conditions compared to other temperate areas due to the influence of two large river plumes (Loire and Gironde). However, in spite of the occurrence of a microphytoplankton bloom during winter and phosphate limitation in spring, the dynamics of the planktonic food web on the continental shelf of the Bay seem to correspond with the characteristics typical of temperate oceans with the dominance of herbivory during spring and the development of the microbial food web under the stable post-bloom environment. Existing plankton data from recent scientific cruises were combined with inverse and network analyses to construct five model ecosystems between late winter and late spring and to investigate the structure and the function of the food web. The analysis of those models confirmed that the absolute amount of biogenic carbon export from the planktonic food web follows a continuum from high carbon export to depth when the microphytoplankton winter bloom is not consumed by grazers to carbon recycling within the microbial food web after the spring bloom when the water column is strongly stratified. Therefore, the winter-spring period corresponds to a situation of high export. The particular hydrological conditions of the Bay of Biscay are not altering the capacity of the planktonic food web to export the greatest absolute amount of carbon during spring to plankton predators such as small pelagic fishes. However, this study showed that, in proportion to the primary production, the relative amount of biogenic carbon export to higher trophic levels does not vary considerably among the three types of planktonic food web function. Bacterial activity seems to have a higher control on relative export than phytoplankton size structure.
\end{abstract}

(C) 2007 Elsevier Ltd. All rights reserved.

Keywords: phytoplankton bloom; plankton; food web; inverse analysis; carbon flows; Atlantic Ocean; Bay of Biscay

\footnotetext{
* Corresponding author.

E-mail address: emarquis@univ-lr.fr (E. Marquis).
}

\section{Introduction}

In marine ecosystems, the fate of primary production depends on the path it takes, usually either the grazing food chain or the microbial food web, which in turn is tied to the 
size of the main algal producers (Azam et al., 1983; Sherr et al., 1986; Sommaruga, 1995; Thingstad and Rassoulzadegan, 1999) and to hydrological conditions (Cushing, 1989; Legendre and Rassoulzadegan, 1996). The different states of the planktonic food web were classified by Legendre and Rassoulzadegan (1996) following a continuum from the system that exports phytoplankton to depth to that which recycles biogenic carbon within the microbial loop. In this scheme, the grazing food chain is at the end of the continuum that exports a large amount of carbon whereas the microbial food web is at the opposite end of the continuum, where the quantity of biogenic carbon exported is low (Legendre and Rassoulzadegan, 1996). Those food web structures also correspond to different hydrological conditions, the microbial food web being more likely when water column stability is at its maximum (Legendre and Rassoulzadegan, 1996).

In temperate oceans, changes in stratification and nutrient availability largely regulate seasonal changes in plankton assemblages (Valiela, 1995). In winter, the primary producers are mixed too deep for positive net photosynthesis in the water column; in spring, increasing light and stratification lead to a phytoplankton bloom event whereas the depletion of nutrients and the abundance of grazers prevent high algal production in summer. It is common to observe diatom blooms at the base of the classical food chain during spring (high nutrient levels), followed by a microbial food web during summer (low nutrient level) (Baretta-Bekker et al., 1995; Bury et al., 2001; Rat'kova and Wassmann, 2002; Odate and Imai, 2003). However, local variations and combinations of the different environmental parameters may result in different patterns of the seasonal biological cycle for each area.

The Bay of Biscay is located on the West coast of France, in the North East Atlantic Ocean under a temperate climate. The seasonal hydrographic conditions of the water column on the continental shelf show specific characteristics. Previous studies in the Bay of Biscay have shown that freshwater discharges from the Loire and the Gironde rivers into the Bay of Biscay create a long-shore flow which may dominate a wide part of the continental shelf at the end of winter (Lazure and Jegou, 1998; Labry et al., 2001). This haline stratification combined with an increase in luminosity may induce phytoplankton blooms (Labry et al., 2001). Such late winter blooms have been observed off the Loire estuary (March 2000, Gohin et al., 2003) and the Gironde estuary (March 1998, Labry et al., 2001). They considerably reduce the amount of nutrients available within the surface layer. Phosphate limitation is enhanced by an excess of nitrate in the runoff of the Loire and Gironde rivers (Labry et al., 2002; Loyer et al., 2006) and tends to result in a dominance of small-sized cells in spring due to their high competitiveness in such an environment (Legendre and Rassoulzadegan, 1995). Consequently, spring represents a change from the diatom-dominated winter community (Herbland et al., 1998) to the dominance of small phytoplankton cells. In spite of the amount of biological information on planktonic communities in this Bay, the available data have not been yet assembled into food webs, to quantify the carbon flows that connect community components from the primary producers to the planktonic grazers. However, since specific hydrographic conditions and seasonal patterns in size structure are occurring in the continental shelf of the Bay of Biscay, it is not clear whether the dynamics of the planktonic food web follow the scheme proposed by Legendre and Rassoulzadegan (1996).

For the present study, data were obtained from cruises over the Bay of Biscay continental shelf in late winter, spring and late spring. Most of the data used here have been analyzed and published. The previous studies focused on specific types of organisms or trophic links such as, for example, the role of phosphorus on planktonic production (e.g. Herbland et al., 1998; Labry et al., 2002), zooplankton grazing activity (e.g. Sautour et al., 2000; Vincent and Hartmann, 2001), or physical parameters (e.g. Puillat et al., 2004). We applied inverse analysis to estimate carbon flows through the planktonic food web. Inverse analysis, evolved from the physical sciences, has been used to infer properties of a system when insufficient data are available to fully define it. Vézina and Platt (1988) were the first to apply this approach to reconstruct material flows through marine food webs. They used an optimization technique that provided a steady-state description of a food web by using ancillary information to constrain the estimation of unknown flows. Since this first application, the inverse analysis method has been used to describe the planktonic food webs of a wide range of marine environments including the North Pacific (Vézina and Savenkoff, 1999), the Baltic Sea (Donali et al., 1999), the English Channel (Vézina and Platt, 1988), the Californian coastal waters (Jackson and Eldridge, 1992), the Florida Bay (Richardson et al., 2003), an atoll lagoon (Niquil et al., 1998, 1999, 2001), the Gulf of St. Lawrence (Vézina et al., 2000) and the Mississippi River plume (Breed et al., 2004). Using inverse analysis, the overall goal of the present study was to determine if the specific hydrological conditions of the Bay of Biscay and the occurrence of winter phytoplankton blooms alter the seasonal development of the structure and carbon fluxes of the planktonic food web in this temperate area.

\section{Material and methods}

\subsection{Study site and hydrological structure of the water column}

The Bay of Biscay (Fig. 1) is an open bay of the eastern Atlantic Ocean characterized by a continental shelf up to $200 \mathrm{~km}$ wide with a surface area of $223,000 \mathrm{~km}^{2}$. The hydrological structure over the shelf is principally influenced by the seasonal dynamics of the Loire and the Gironde river plumes (Lazure and Jegou, 1998). Data for the study were obtained from three different oceanographic cruises (Fig. 1) between late winter and late spring. In late winter, two Gironde plume water masses were sampled: Biomet $3 \mathrm{~N}\left(45^{\circ} 50 \mathrm{~N}-1^{\circ} 50 \mathrm{~W}, 28\right.$ February to 03 March 1998$)$ and Biomet $3 \mathrm{~S}\left(45^{\circ} 30 \mathrm{~N}-1^{\circ} 40 \mathrm{~W}\right.$, 07 March to 10 March 1998). In spring, we sampled two stations (PEL-A, $47^{\circ} 11 \mathrm{~N}-3^{\circ} 15 \mathrm{~W}$, and PEL-B, $47^{\circ} 04-4^{\circ} 19 \mathrm{~W}$, 


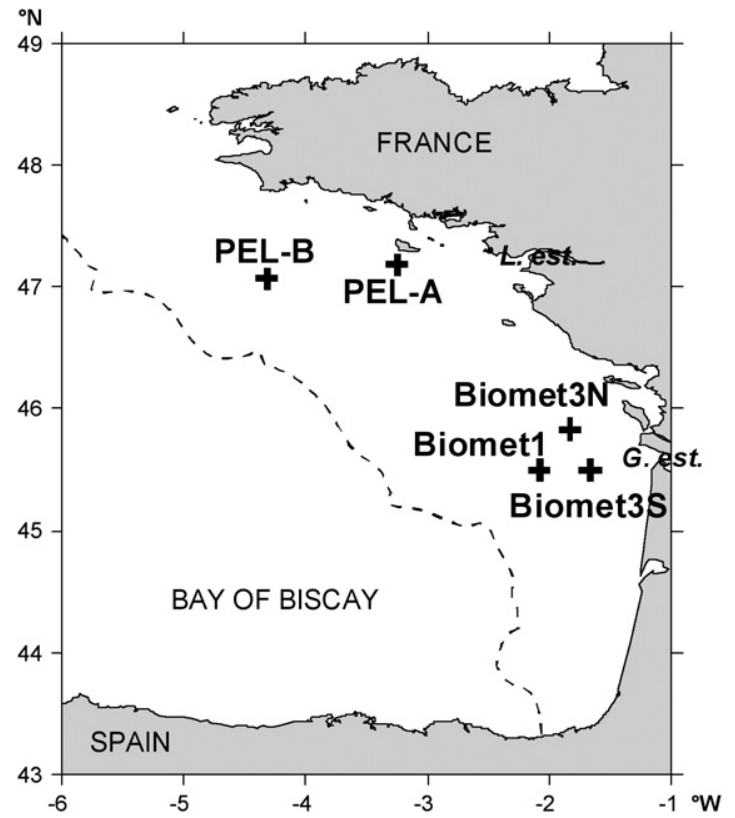

Fig. 1. Map of the Bay of Biscay showing the five stations of the study. "L. est." means Loire estuary and "G. est." means Gironde estuary. Dashed line is a schematic representation of the continental shelf limits.

respectively, 11 May and 12 May 2001) located on a Loire plume transect across the continental shelf (cruise PEL2001). In late spring, a single water mass was followed for eight consecutive days at a station within the Gironde plume (Biomet1, $45^{\circ} 30 \mathrm{~N}-2^{\circ} 05 \mathrm{~W} 18$ May to 25 May 1995 ).

Salinity and temperature profiles were measured using a CTD (conductivity-temperature-density) probe. At all five stations, the water column was stratified due to low salinity from river runoff (Fig. 2). The stratification may be illustrated by $\Delta S$ and $\Delta T$ that are the difference in salinity $(S)$ and temperature $(T)$ between the surface and the bottom waters. In late winter, salinity stratification through the photic zone was strongest $(\Delta S \geq 1)$ with low temperatures and little evidence of surface warming (surface $T<12^{\circ} \mathrm{C}, \Delta T=0.7^{\circ} \mathrm{C}$, e.g. Biomet3N). In spring, surface warming progressed (surface $T>13{ }^{\circ} \mathrm{C}, \Delta T=1.3^{\circ} \mathrm{C}$, e.g. PEL-B) and was maximal in late spring $\left(\Delta T=1.7^{\circ} \mathrm{C}\right.$, Biomet1).

\subsection{Inverse analysis: principle and method}

The first step of the inverse approach of Vézina and Platt (1988) is to build an a priori model that describes all possible carbon flows among the trophic compartments. The system is assumed to be in steady state during the period modeled and the carbon flows that are going in and out of each compartment are balanced. A set of equations is built with the massbalanced equations for each compartment. Moreover, field determinations of rates of planktonic processes, such as photosynthetic and grazing rates, allow us to formulate additional linear equations that express the observations in terms of flows. The equations describing the system and the data can be written in matrix-vector form:
$\mathbf{A} \times \mathbf{r}=\mathbf{b}$

where $\mathbf{A}$ is a matrix of coefficients; $\mathbf{r}$ is the vector of possible flows; and $\mathbf{b}$ is the vector of results for the equalities. The inverse solution consists in finding the vector $\mathbf{r}$ that provides the best estimate of $\mathbf{b}$.

Since the set of equations and equalities are insufficient to determine a unique solution for the entire system (i.e. a large fraction of the a priori model flows remain unknown), two other criteria are used to obtain a single solution (Vézina and Platt, 1988). The first one is a set of constraints providing limits for the biological processes such as respiration, assimilation efficiency or ingestion. The system of inequalities can be written as:

$\mathbf{G} \times \mathbf{r} \geq \mathbf{h}$

where $\mathbf{G}$ is a matrix of coefficients; and $\mathbf{h}$ is the vector of solutions for the inequalities.

Applying such constraints reduces the domain of solutions, but it still allows an infinite number of possible solutions. The final criterion is based on the parsimony principle and assumes that the best set of flows is that with the smallest sum of squares (Vézina, 1989).

The model structure and solution technique are described in detail in Vézina and Platt (1988) and Vézina and Pahlow (2003). The solution was computed using Matlab ${ }^{\odot}$.

\subsection{A priori model}

The a priori model represents all the allowed carbon flows and defines the system (Fig. 3). The model includes eight compartments: small phytoplankton (Ph1, $<2 \mu \mathrm{m})$, intermediate phytoplankton $(\mathrm{Ph} 2,2-20 \mu \mathrm{m})$, large phytoplankton $(\mathrm{Ph} 3$, $>20 \mu \mathrm{m})$, bacteria $(\mathrm{Bac})$, protozoa $($ Pro $=$ heterotrophic flagellates and ciliates $<200 \mu \mathrm{m}$ ), mesozooplankton (Mes = mesozooplankton, i.e. metazoan zooplankton $>200 \mu \mathrm{m}$ ), dissolved organic carbon (DOC) and detritus (Det).

The a priori model considers 32 average flows of carbon below one square meter of the photic zone during 1 day (Table 1). Gross primary production (GPP) is the only external carbon input (Fig. 3). Outputs include respiration for all living compartments, as well as detritus sinking (carbon sedimentation, Fig. 3) and predation on mesozooplankton (carbon export, Fig. 3). All living compartments except bacteria contribute to the detritus pool through cell lysis, feces production and sloppy feeding. Bacteria are assumed to be too small to contribute to the particulate carbon pool upon viral lysis, but through lysis do contribute to the DOC pool. Mortality other than predation is implicitly included in the detritus term (Richardson and Daniels, 2003). We assume that Ph1 does not contribute to the sedimentation flow, as their size is too small to generate a sedimentation flux. All living compartments contribute to the DOC pool through excretion.

Particulate detritus transformation into DOC includes direct dissolution as well as hydrolysis catalyzed by the exoenzymatic activity of bacteria (Ducklow and Carlson, 1992). 


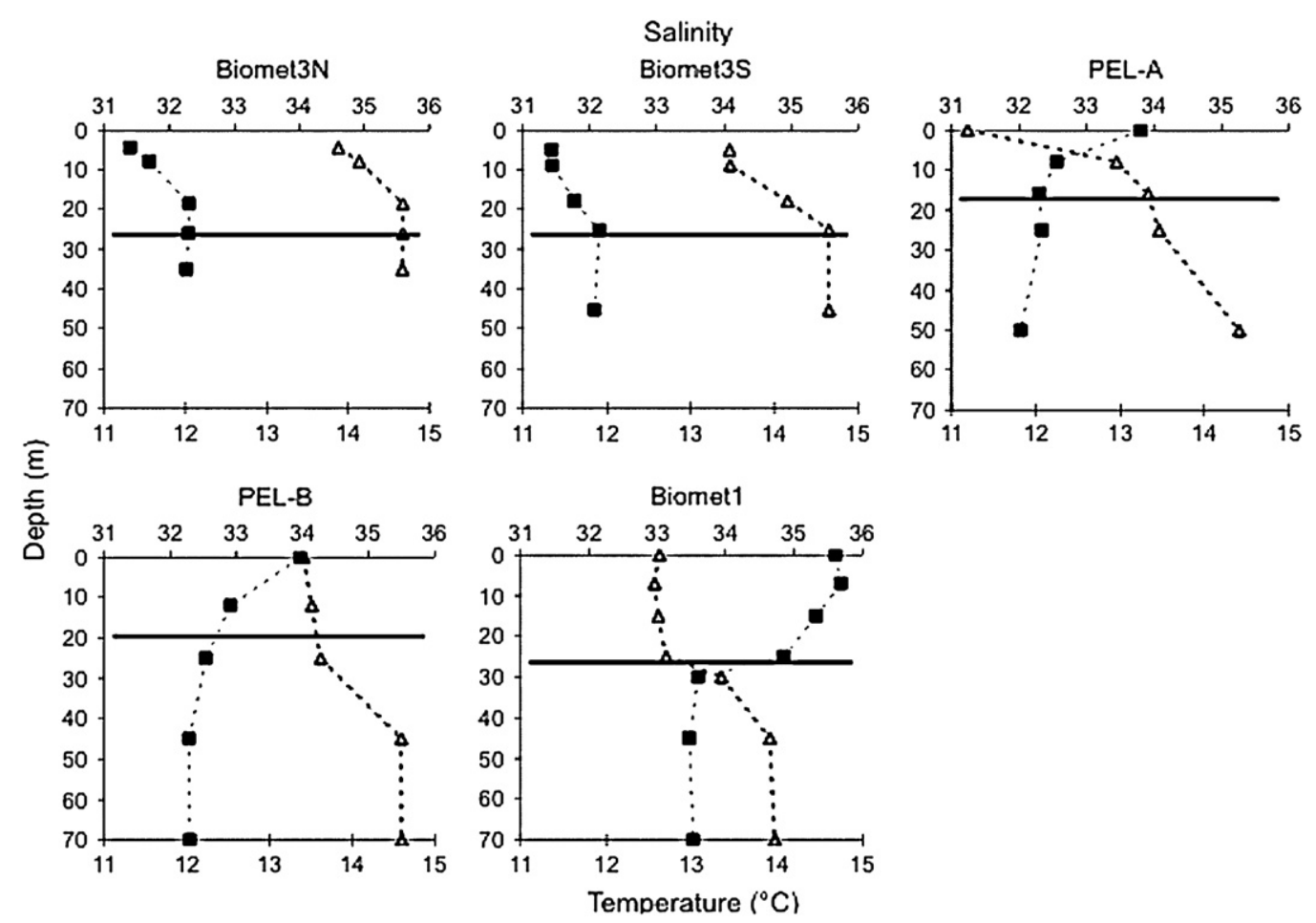

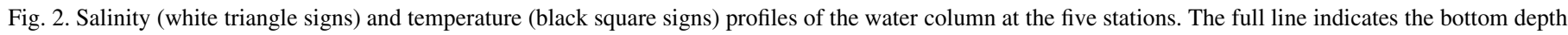
of the photic layer.

DOC represents the only bacterial nutrient source. Protozoa grazes on bacteria and small plus intermediate phytoplankton. Mesozooplankton is assumed to graze on intermediate and large phytoplankton as well as protozoa but not on small phytoplankton. It has been shown that most copepods do not graze efficiently on small phytoplankton (Sherr et al., 1986). We consider that both protozoa and mesozooplankton are able to consume detritus.

\subsection{Data and constraints}

All collected data were translated into a set of equations (Table 2): phytoplankton and bacteria production in all five models; phytoplankton-to-mesozooplankton flows in the late winter and late spring models (Biomet3N and Biomet3S, and Biomet1); phytoplankton-to-protozoa (grazing), mesozooplankton-to-detritus (fecal pellets) and detritus-to-loss (sedimentation) carbon flows in the late spring model (Biomet1). They were expressed as flux $\left(\mathrm{mg} \mathrm{C} \mathrm{m}^{-2} \mathrm{~d}^{-1}\right)$ integrated over the photic zone whose depth was determined from PAR profiles: $26 \mathrm{~m}$ in Biomet3N and in Biomet3S, $17 \mathrm{~m}$ in PEL-A, $19 \mathrm{~m}$ in PEL-B and $25 \mathrm{~m}$ in Biomet 1. In late winter and late spring (Biomet3N and Biomet3S, and Biomet1), when a water mass was followed over several days, we used the mean value of each type of collected data. Those collected data transformed in equations permitted us to determine six of the 32 carbon flows for late winter (Biomet3N and Biomet3S), four of the 32 for spring (PEL-A and PEL-B) and 10 of the 32 for late spring (Biomet1).

Water samples were collected using Niskin bottles. Sizefractionated $(<2 \mu \mathrm{m}, 2-20 \mu \mathrm{m},>20 \mu \mathrm{m})$ primary production was assessed by in situ incubation of seawater with ${ }^{14} \mathrm{C}$ from sunrise to sunset and filtrations through different mesh sizes, according to Labry et al. (2002). Since the long incubations increased the likelihood of labeled carbon being respired to $\mathrm{CO}_{2}$ (Sakshaug et al., 1997), it was assumed that those measurements did not correspond to the total gross primary production but to the gross production minus half of the daily respiration (Table 2). Size-fractionated ( $<2 \mu \mathrm{m}, 2-20 \mu \mathrm{m},>20 \mu \mathrm{m}$ ) chlorophyll $a$ concentrations were assessed by filtration and fluorometric acidification according to Labry et al. (2001). Phytoplankton carbon was estimated from chl $a$ concentrations assuming a constant C:chl $a$ w:w ratio of 50:1 (Labry et al., 2005).

Bacterial production was estimated by the $\left[{ }^{3} \mathrm{H}\right]$ methylthymidine (TdR) incorporation method (Fuhrman and Azam, 1982; Labry et al., 2002). Samples for bacterial counts were preserved with borate-buffered formaldehyde ( $2 \%$ final concentration) and bacteria were enumerated by direct counting after staining with DAPI (Porter and Feig, 1980; Labry et al., 2002). Values were converted to bacterial production and biomass assuming a cell content of $16 \mathrm{fgC}$ (Labry et al., 2002).

Ciliates and flagellates were fixed (respectively, with glutaraldehyde and paraformaldehyde), stained (respectively, with proflavin hemisulfate solution and primulin) and enumerated (under inverted fluorescence and epifluorescence microscopy) according to methods from Haas (1982), Caron (1983) and Sherr et al. (1994) modified by Dupuy et al. (1999). The mean cell volume of each taxon was calculated by equating the shape to standard geometric configurations. The cell volume was converted into carbon units using a theoretical 


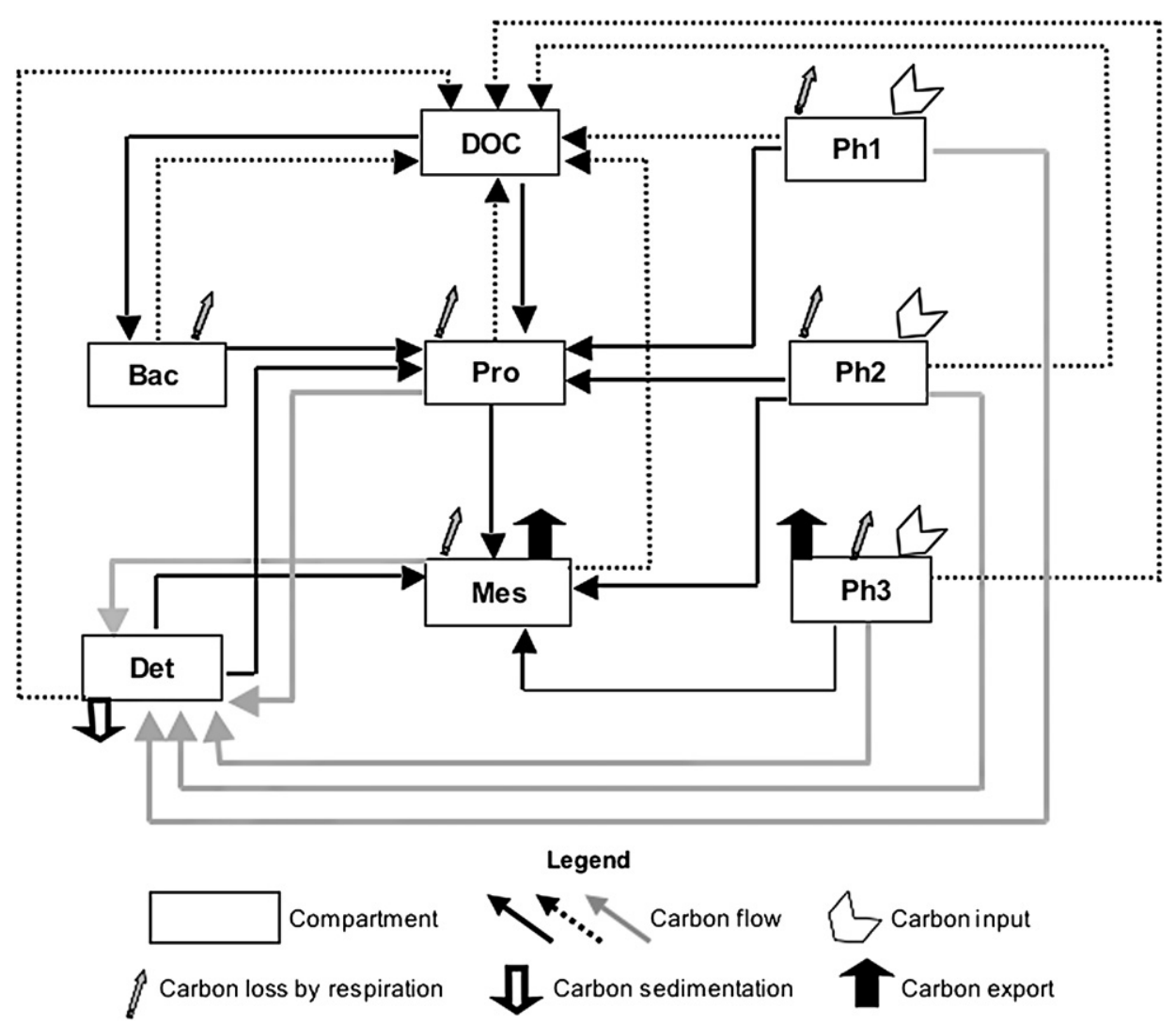

Fig. 3. A priori model used to build the five planktonic food web systems. Definitions of abbreviations are Ph1: picophytoplankton $(<2 \mu \mathrm{m})$, Ph2: nanophytoplankton $(2-20 \mu \mathrm{m}), \mathrm{Ph} 3$ : microphytoplankton $(>20 \mu \mathrm{m})$, Bac: bacteria, Pro: protozoa (ciliates and flagellates, $20-200 \mu \mathrm{m})$, Mes: mesozooplankton $(>200 \mu \mathrm{m})$, Det: detritus and DOC: dissolved organic matter.

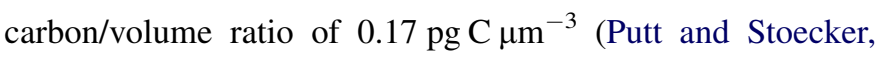
1989), corrected for glutaraldehyde fixative (Leakey et al., 1994). Since no samples for protozoan biomass existed for stations PEL-A and PEL-B, we used representative data from neighboring stations studied during the same PEL2001 cruise (different by less than 4 days and $20 \mathrm{~km}$ ). Those stations were chosen according to their similarity with PEL-A and PEL-B for temperature, salinity and nutrient profiles.

Mesozooplankton was collected from vertical tows using a $200 \mu \mathrm{m}$ mesh WP2 net, preserved in buffered formaldehyde (final concentration $2 \%$ ) and counted under a binocular microscope. The individual dry weights were determined by weighing three aliquots of 30 individuals of each species that have been previously rinsed with distilled water and dried at $60{ }^{\circ} \mathrm{C}$ for 1 day. Carbon biomass was determined by multiplying dry weights of each species by a factor of 0.4 (Sautour et al., 2000). Phytoplankton grazing rates by mesozooplankton were estimated by gut content experiments for Biomet3N and Biomet3S (Sautour et al., 2000). Phytoplankton grazing by microzooplankton was measured by the dilution method for Biomet1 only (Landry and Hassett, 1982; Sautour et al., 2000). In this study, we assumed that microzooplankton grazing activity was represented by protozoa grazing as the metazoan microplankton biomass was close to zero within the incubation bottles (Sautour, pers. comm.). Those grazing flows were measured on the entire phytoplankton compartment (the three size-classes together). Sediment traps were used to estimate sinking rates of fecal pellets (short term sinking, 1-3 h) and downward particulate organic matter flow (long term sinking, $20 \mathrm{~h}$ ) for Biomet1 (Sautour et al., 2000).

In order to constraint the remaining unknown flows (26 in late winter, 28 in spring and 22 in late spring), 36 inequalities were applied to the five models (Online supplement). The inequalities used for this work were a combination of those described in Vézina and Platt (1988), Vézina and Pace (1994) and Vézina et al. (2000). They constrain the respiration of phytoplankton, bacteria, protozoa and mesozooplankton; the DOC excretion of phytoplankton, protozoa and mesozooplankton; the production efficiency of bacteria, protozoa and mesozooplankton; the ingestion of protozoa and mesozooplankton, and the assimilation efficiency of protozoa and mesozooplankton; the dissolution and the sedimentation of detritus (Online supplement). The field estimates of temperature, bacteria, protozoa and mesozooplankton stocks as well as specific cell and body mass were used for constraint calculations at each station (i.e. maximum specific respiration and maximum specific ingestion for the heterotrophic compartments) (Online supplement).

\subsection{Model analysis}

The planktonic food web models that result from the inverse analysis were analyzed using the network analysis of 
Table 1

Flows formulations, descriptions and values $\left(\mathrm{mg} \mathrm{C} \mathrm{m}^{-2} \mathrm{~d}^{-1}\right)$ issued from direct measures (bold font) and from inverse analysis calculations (normal font)

\begin{tabular}{|c|c|c|c|c|c|c|}
\hline \multirow[t]{2}{*}{ Symbol } & \multirow[t]{2}{*}{ Description } & \multicolumn{2}{|c|}{ Late winter } & \multicolumn{2}{|l|}{ Spring } & \multirow{2}{*}{$\frac{\text { Late spring }}{\text { Biomet1 }}$} \\
\hline & & Biomet3 & Biomet3 & PEL-A & PEL-B & \\
\hline CgppTOph1 & Cross primary production of small phytoplankton & 58.9 & 45.1 & 653.8 & 802.2 & 285.0 \\
\hline CgppTOph2 & Gross primary production of intermediate phytoplankton & 155.6 & 151.9 & 255.9 & 316.9 & 246.9 \\
\hline CgppTOph3 & Gross primary production of large phytoplankton & 281.9 & 142.3 & 756.0 & 25.5 & 99.9 \\
\hline Cph1TOres & Respiration by small phytoplankton & 17.7 & 13.5 & 43.6 & 40.1 & 14.3 \\
\hline Cph1TOpro & Grazing of small phytoplankton by protozoa & 16.2 & 1.4 & 301.4 & 331.5 & 110.2 \\
\hline Cph1TOdet & Detritus production by small phytoplankton & 20.9 & 12.8 & 247.8 & 299.4 & 38.5 \\
\hline Cph1TOdoc & DOC excretion by small phytoplankton & 4.1 & 17.4 & 61.0 & 131.2 & 122.1 \\
\hline Cph2TOres & Respiration by intermediate phytoplankton & 36.0 & 7.6 & 76.8 & 58.0 & 12.3 \\
\hline Cph2TOpro & Grazing of intermediate phytoplankton by protozoa & 51.5 & 30.1 & 61.4 & 0.0 & 86.8 \\
\hline Cph2TOmes & Grazing of intermediate phytoplankton by mesozooplankton & $\mathbf{0 . 0}$ & 12.1 & 92.1 & 131.2 & 33.9 \\
\hline Cph2TOdet & Detritus production by intermediate phytoplankton & 56.1 & 41.4 & 7.8 & 101.9 & 15.1 \\
\hline Cph2TOdoc & DOC excretion by intermediate phytoplankton & 12.0 & 60.7 & 17.9 & 25.9 & 98.8 \\
\hline Cph3TOres & Respiration by large phytoplankton & 16.2 & 7.1 & 37.8 & 7.7 & 30.0 \\
\hline Cph3TOmes & Grazing of large phytoplankton by mesozooplankton & 26.6 & 19.0 & 365.3 & 16.1 & 25.1 \\
\hline Cph3TOdet & Detritus production by large phytoplankton & 143.3 & 48.4 & 281.1 & 0.0 & 6.3 \\
\hline Cph3TOdoc & DOC excretion by large phytoplankton & 95.9 & 67.7 & 71.8 & 1.8 & 38.5 \\
\hline CproTOres & Respiration by protozoa & 84.6 & 74.5 & 256.8 & 156.5 & 210.4 \\
\hline CproTOmes & Grazing of protozoa by mesozooplankton & 38.4 & 33.9 & 116.7 & 117.1 & 112.0 \\
\hline CproTOdet & Detritus production by protozoa & 15.4 & 13.6 & 46.7 & 87.8 & 44.8 \\
\hline CproTOdoc & DOC excretion by protozoa & 15.4 & 13.6 & 46.7 & 40.2 & 80.8 \\
\hline CmesTOres & Respiration by mesozooplankton & 46.8 & 34.0 & 230.4 & 155.3 & 61.3 \\
\hline CmesTOdet & Detritus production by mesozooplankton & 26.7 & 19.4 & 131.7 & 88.7 & 35.0 \\
\hline CmesTOdoc & DOC excretion by mesozooplankton & 13.4 & 9.7 & 65.8 & 44.4 & 17.5 \\
\hline CmesTOlos & Outflows of mesozooplankton by predation & 46.8 & 34.0 & 230.4 & 155.3 & 61.2 \\
\hline CdocTObac & DOC absorption by bacteria & 172.2 & 208.0 & 399.0 & 331.4 & 502.0 \\
\hline CbacTOres & Respiration by bacteria & 86.1 & 84.4 & 348.4 & 293.5 & 190.3 \\
\hline CbacTOpro & Grazing of bacteria by protozoa & 86.1 & 104.0 & 50.6 & 37.8 & 251.0 \\
\hline CbacTOdoc & DOC excretion by bacteria & 0.0 & 19.6 & 0.0 & 0.0 & 60.7 \\
\hline CdetTOdoc & Detritus dissolution into DOC & 31.5 & 19.3 & 135.7 & 88.0 & 83.7 \\
\hline CdetTOpro & Detritus consumption by protozoa & 0.0 & 0.0 & 53.6 & 32.2 & 0.0 \\
\hline CdetTOmes & Detritus consumption by mesozooplakton & 68.6 & 32.1 & 84.3 & 179.2 & 4.0 \\
\hline CdetTOlos & Outflows of detritus by sedimentation & 162.4 & 84.1 & 441.5 & 278.4 & 52.0 \\
\hline
\end{tabular}

Ulanowicz (1999). The 'Netwrk 4.2' program (Ulanowicz, 1999) was used to calculate indices to characterize the food webs in terms of throughput, carbon export and carbon recycling. The flow of matter through a compartment is its throughput (sum of flows entering into a compartment $=$ sum of leaving flows). This number quantifies the gross production of a compartment. The total throughput is a measure of the total activity of the system (Ulanowicz, 1986). The Finn Cycling Index (FCI) (Finn, 1976) is defined as the ratio of the sum of carbon flows in cyclic pathways to the sum of all carbon flows in the system. The calculation of the herbivory/detritivory ratio completed the structure analysis. Herbivory refers to the flow from primary producers to the second trophic level and detritivory refers to the flow from the detrital pool to the same trophic level. Finally, the turnover time of each compartment was calculated as the ratio between its biomass (collected data) and its net production (throughput-respiration-excretion).

\subsection{Sensitivity analysis}

The goal of the sensitivity analysis was to test the effect of a change in the input data on the carbon flow estimates. Each datum was tested individually. We changed the chosen item by plus or minus $20 \%$ and reran the inverse analysis. The results of these changes, expressed as network indices, were compared to the reference model value. The model for each station was analyzed in the same way. Since less data were collected and used in the set of equations for the spring models (PEL-A and PEL-B), a second sensitivity analysis was realized in order to determine the influence of the higher input data used to construct the late winter and late spring models (Biomet3N and Biomet3S, and Biomet1) on the general characteristics found for each system. This second sensitivity analysis was done by running the three Biomet models with the same set of input equalities as the two PEL models, i.e. four equalities with three phytoplankton productions and one bacterial production (Table 2).

\section{Results}

Data collection and inverse analysis led to the estimation of all 32 carbon flows for each station (Table 1). The state of water column stratification and the magnitude of phytoplankton production order the stations into three seasonal regimes: late winter (Biomet3N, Biomet3S), spring (PEL-A, PEL-B) and late spring (Biomet1). 
Table 2

Field data used as equalities to build the five systems. "Not est." means "not estimated". Values are in $\mathrm{mg} \mathrm{C} \mathrm{m}^{-2} \mathrm{~d}^{-1}$

\begin{tabular}{|c|c|c|c|c|c|c|}
\hline \multirow[t]{2}{*}{ Data } & \multirow[t]{2}{*}{ Equation } & \multicolumn{2}{|l|}{ Late winter } & \multicolumn{2}{|l|}{ Spring } & \multirow{2}{*}{$\frac{\text { Late spring }}{\text { Biomet1 }}$} \\
\hline & & Biomet $3 \mathrm{~N}$ & Biomet3S & PEL-A & PEL-B & \\
\hline Picophytoplankton production & CgppTOph1 - 0.5 Cph1Tores & 50.1 & 38.4 & 632.0 & 782.1 & 277.9 \\
\hline Nano-phytoplankton production & CgppTOph2 - 0.5 Cph2Tores & 137.6 & 148.1 & 217.5 & 287.9 & 240.7 \\
\hline Microphytoplankton production & CgppTOph3 - 0.5 Cph3TOres & 273.8 & 138.7 & 737.1 & 21.7 & 84.9 \\
\hline Bacterial production & CbacTOpro & 86.1 & 104.0 & 50.6 & 37.8 & 251.0 \\
\hline $\begin{array}{l}\text { Mesozooplankton grazing } \\
\text { on nano- and microphytoplankton }\end{array}$ & Cph2Tomes + Cph3TOmes & 65.0 & 65.0 & Not est. & Not est. & 171.0 \\
\hline $\begin{array}{l}\text { Protozoa grazing } \\
\text { on pico- and nano-phytoplankton }\end{array}$ & Cph1TOpro + Cph2TOpro & Not est. & Not est. & Not est. & Not est. & 197.0 \\
\hline $\begin{array}{l}\text { Mesozooplankton fecal } \\
\text { pellet sinking rate }\end{array}$ & CmesTOdet & Not est. & Not est. & Not est. & Not est. & 35.0 \\
\hline Sedimentation of detritus & CdetTOlos & Not est. & Not est. & Not est. & Not est. & 52.0 \\
\hline
\end{tabular}

\subsection{Primary and bacterial production}

Total net primary production (Fig. 4a) was relatively low in late winter and late spring and was the highest during spring. The proportion of small phytoplankton production (Ph1 and $\mathrm{Ph} 2$ ) was low in late winter (38 and $65 \%$ of total net primary production in Biomet $3 \mathrm{~N}$ and Biomet3S, respectively), was more important in spring (55 and $98 \%$ of the total net primary production in PEL-A and PEL-B) and was also high in late spring ( $88 \%$ of the total in Biomet1).

Net bacterial production (Fig. 4b) was low in late winter and even lower in spring but considerably greater during late spring. In proportion to net primary production (Fig. 4b), bacterial net production was intermediate in late winter (20 to $46 \%$ of net primary production), low in spring $(<5 \%$ of net primary production for PEL-A and B) and highest in late spring (54\% of net primary production for Biomet1).

\subsection{Internal flows to predators}

Internal flows are inferred from the inverse analysis. In late winter, the diet of protozoa (Fig. 5a) was mainly composed of heterotrophic bacteria. During spring, the major food source was picophytoplankton (Ph1), which contributed $64 \%$ in PEL-A and $83 \%$ in PEL-B. In late spring, protozoan diet was composed of bacteria and phytoplankton in roughly equal shares. For mesozooplankton, detritus was the main source of food during late winter. In spring, their diet was herbivorous in PEL-A and omnivorous in PEL-B, whereas it was largely carnivorous in late spring (Pro $=64 \%$ of total diet in Biomet1).

Total ingestion rates of protozoa and mesozooplankton (cf. Fig. 5a and b) were more or less equivalent in late winter. In spring, the mesozooplankton ingestion rate was higher but corresponded to much longer turnover times of carbon $(>3$ days, Table 3). In late spring, the reverse was true, with total ingestion rates of $448 \mathrm{mg} \mathrm{C} \mathrm{m}^{-2} \mathrm{~d}^{-1}$ for protozoa and $175 \mathrm{mg} \mathrm{C} \mathrm{m}^{-2} \mathrm{~d}^{-1}$ for mesozooplankton in Biomet1. The turnover times of carbon within the protozoa compartment were short (0.73 days, Table 3$)$ but longer than in spring (0.100.32 days, Table 3 ).

\subsection{Carbon recycling and carbon outflows}

The Finn Cycling Index (FCI, Fig. 6) was high in late winter $(>10 \%)$, lower in spring $(<10 \%)$ and highest in late spring $(26 \%)$. The FCI correlated negatively with the

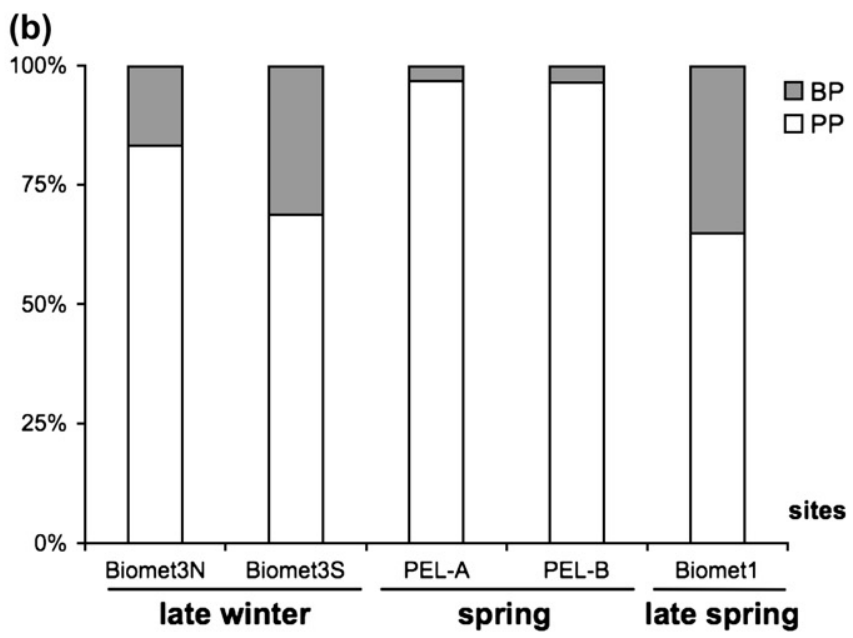

Fig. 4. (a) Contribution of the three phytoplankton size-classes ( $\mathrm{Ph} 1, \mathrm{Ph} 2$ and $\mathrm{Ph} 3)$ to the net primary production $\left(\mathrm{mg} \mathrm{C}^{-2} \mathrm{~d}^{-1}\right)$ and (b) scaled net primary and bacterial production (PP and BP as percentages of the sum of both production terms) for the five planktonic food web systems. 
(a)

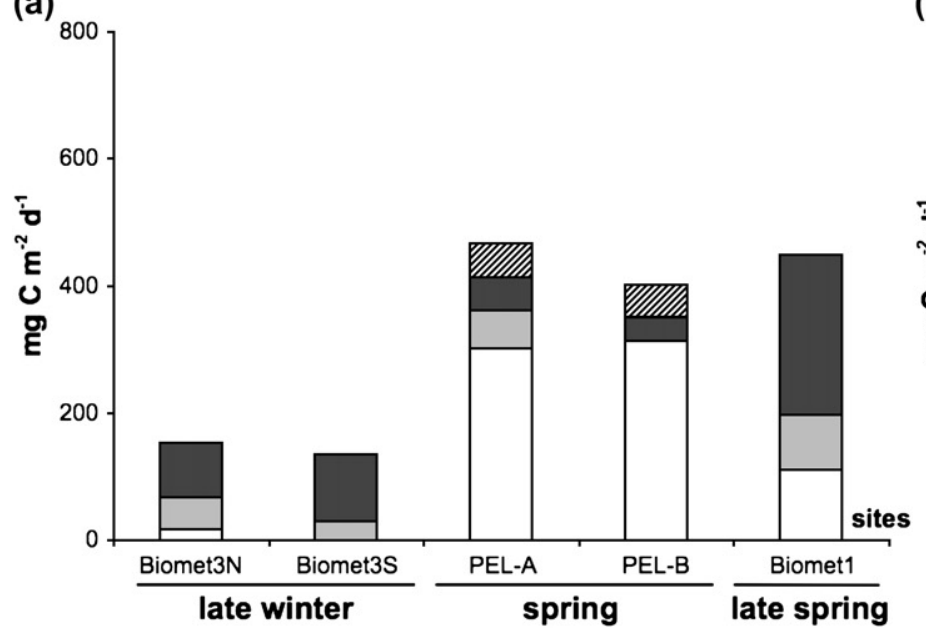

(b)

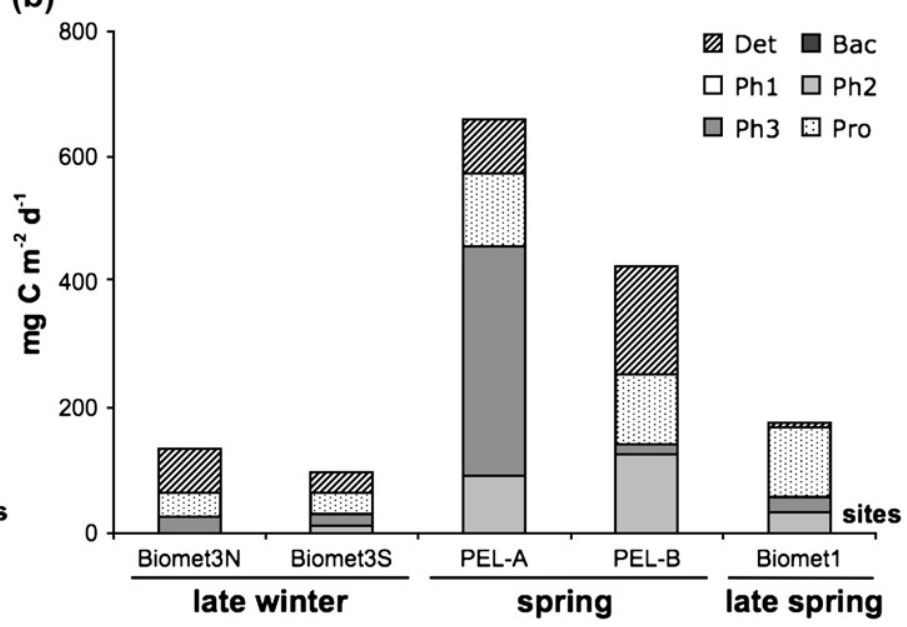

Fig. 5. Contribution of each compartment $\left(\mathrm{mg} \mathrm{C} \mathrm{m}^{-2} \mathrm{~d}^{-1}\right)$ to the consumption of (a) the protozoa and (b) mesozooplankton. Definitions of abbreviations are Ph1: picophytoplankton $(<2 \mu \mathrm{m})$, Ph2: nano-phytoplankton $(2-20 \mu \mathrm{m})$, Ph3: microphytoplankton $(>20 \mu \mathrm{m})$, Bac: bacteria, Pro: protozoa (ciliates and flagellates, 20-200 $\mu \mathrm{m})$ and Det: detritus.

herbivory/detritivory ratio and positively with the ratio of bacterial to primary production. When the FCI was high, such as in late winter and late spring, the herbivory/detritivory ratio was less than 0.5 whereas this ratio was greater than 0.8 during spring (when the FCI was low).

The turnover times of picophytoplankton were very long in late winter (more than 8 days, Table 3). Without considering those values, the phytoplankton turnover times ranged from 0.4 to 4.3 days with the lowest values for pico- and nanophytoplankton. The pico- and microphytoplancton and protozoa showed their lowest carbon turnover times during spring (PEL-A and PEL-B, Table 3). In late winter, the turnover times were the highest for most of the compartments whereas in late spring, the mesozooplankton turnover time was the lowest over the five model systems.

The major carbon outflow from the system (Fig. 7) was respiration. This carbon outflow showed the highest variations between late winter and late spring representing from $57 \%$ of the total carbon loss (equivalent to total gross primary production) in late winter up to $82 \%$ in late spring. Carbon sedimentation represented from $33 \%$ of total gross primary production in late winter down to $8 \%$ in late spring. Predation on mesozooplankton did not show large variations. It barely exceeded $10 \%$ of the total outflows in late winter; it was greater than $13 \%$ in spring and relatively low again in late spring $(9 \%)$.

\subsection{Sensitivity analysis}

The five network indices responded differently to the perturbations in the input data. The most sensitive index was the herbivory on detritivory ratio (Online supplement) with a maximum variation of $40 \%$ in late winter (Biomet3S) and the least sensitive was the predation/total loss ratio with a maximal variation of approximately $18 \%$ (PEL-A). Similarly, the effect of perturbations in input values varied among models.

Table 3

Biomass $\left(\mathrm{mg} \mathrm{C} \mathrm{m}^{-2}\right)$ and turnover times of carbon (days) of the six living compartments. The turnover time was calculated by dividing the biomass by the net production calculated with inverse analysis $\left(\mathrm{mg} \mathrm{C} \mathrm{m}^{-2} \mathrm{~d}^{-1}\right)$. Definitions of abbreviations are Ph1: picophytoplankton $(<2 \mu \mathrm{m})$, Ph2: nano-phytoplankton $(2-20 \mu \mathrm{m}), \mathrm{Ph} 3$ : microphytoplankton $(>20 \mu \mathrm{m})$, Bac: bacteria, Pro: protozoa (ciliates and flagellates, $20-200 \mu \mathrm{m})$, Mes: mesozooplankton $(>200 \mu \mathrm{m})$

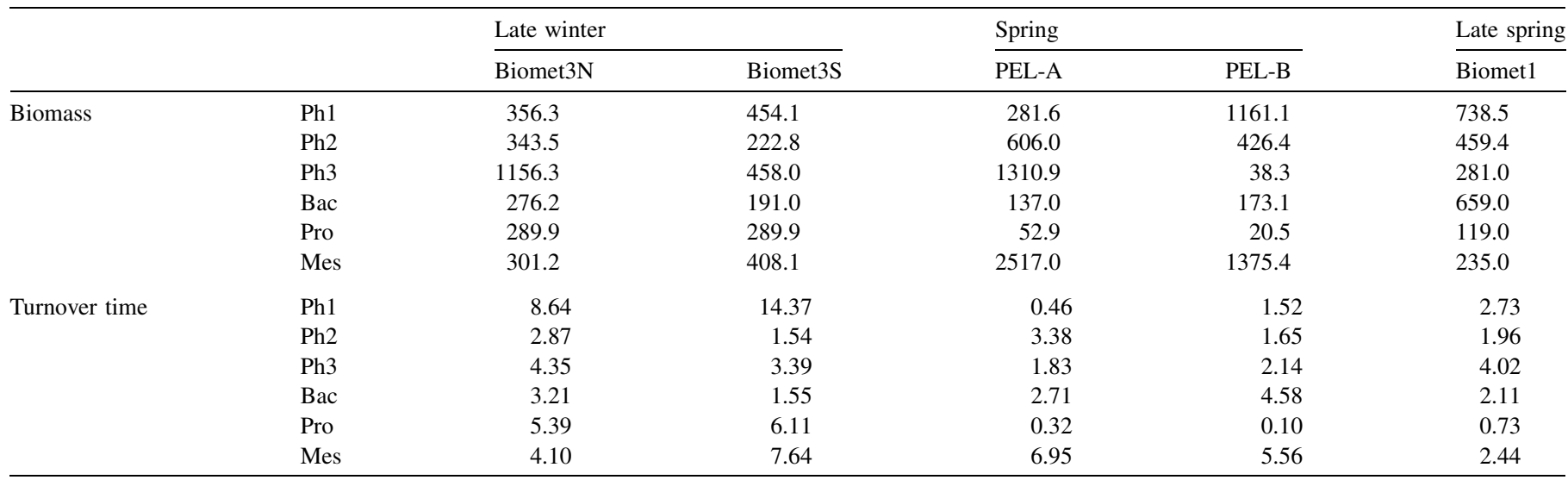




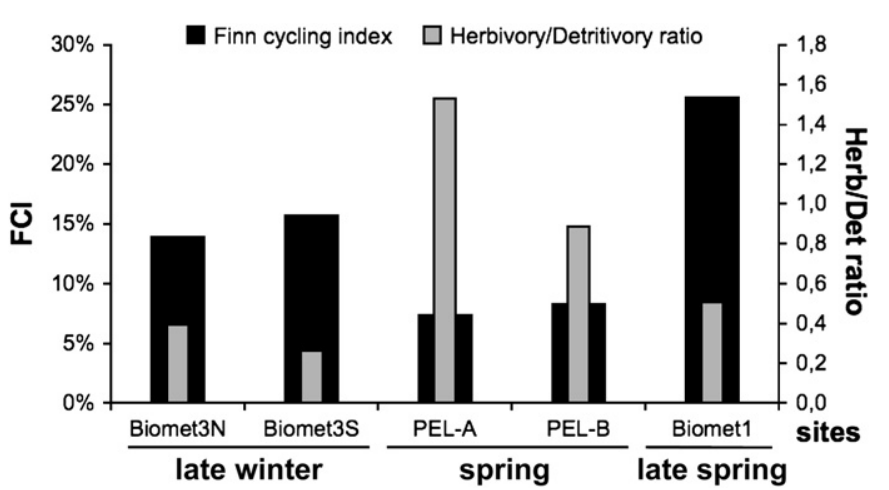

Fig. 6. Finn Cycling Index and herbivory/detritivory ratio, respectively, black and grey bars, within the five models.

Thus, one spring model (PEL-A) was mostly influenced by $\mathrm{Ph} 3$ production and bacterial biomass (Online supplement), while the late spring model (Biomet1) was clearly influenced by $\mathrm{Ph} 1$ production and bacterial production.

Overall, the sensitivity analysis demonstrated that a $20 \%$ change of the input values did not significantly change the main characteristics of the models (Online supplement). Thus, in the reference models, values of total system throughput, herbivory on detritivory ratio, predation/total loss ratio and total respiration were highest for the two spring models. This pattern remained unchanged after sensitivity analysis: for example, after sensitivity analysis, the minimum Total System Throughput of the two spring systems $\left(>3700 \mathrm{mg} \mathrm{C} \mathrm{m}^{-2} \mathrm{~d}^{-1}\right.$ ) was greater than the maximum values for the other three systems $\left(<3290 \mathrm{mg} \mathrm{C} \mathrm{m}^{-2} \mathrm{~d}^{-1}\right)$. Conversely, the minimum Finn Cycling Index was higher for the two late winter and the late spring models $(>13 \%)$ than for the two spring models $(<8.5 \%)$.

We also analyzed the sensitivity of the five main network indices for the late winter and late spring models to using the more restricted input data set characteristic of the two spring models (i.e. equalities for primary and bacterial production only, Table 2). For late winter (Biomet3N and Biomet3S), the most sensitive were the herbivory/detritivory ratio and the ratio of predation/total carbon loss (variations up to $\pm 100 \%$

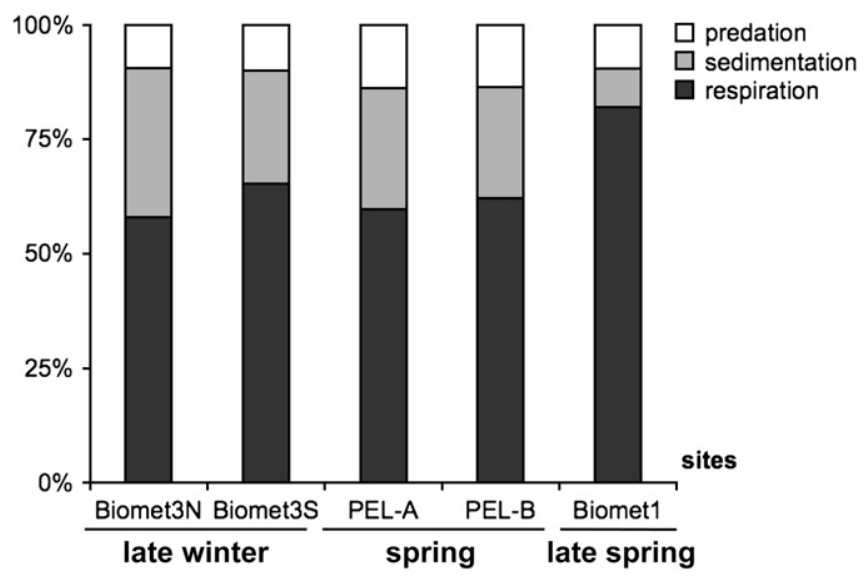

Fig. 7. Proportion of the three pathways of carbon loss out of the five planktonic food web systems (in percentage of the total carbon loss). from the reference result, Online supplement). However, for late spring (Biomet1), none of the indices diverged more than $\pm 25 \%$ from the reference result (Online supplement).

\section{Discussion}

We use inverse analysis to define the seasonal patterns in the carbon flows through the planktonic food web of the Bay of Biscay. Our results suggest that the food web functioning has strong internal variations from late winter to late spring but low relative changes in the capacity to export carbon to plankton predators. Prior to analyzing the patterns in the planktonic food web dynamics in detail, we assess the interpretation in terms of seasonal changes and the confidence in our inverse calculations.

\subsection{Seasonal interpretation of the results}

This study dealt with data coming from different areas of the continental shelf of the Bay of Biscay and different cruises that were not carried out the same year. However, its goal was to compare the planktonic food web models resulting from each data set in order to identify seasonal differences in food web dynamics in the Bay. This interpretation is possible when considering the general hydrological and plankton dynamics of the Bay. The seasonal phytoplankton development is the same seaward of the Loire and the Gironde river plumes, with a late winter bloom of diatoms followed by a short spring bloom and then a dominance of small phytoplankton (Labry et al., 2001; Gohin et al., 2003, 2005; Loyer et al., 2006). These seasonal cycles are not synchronized between the south and the north parts of the Bay, as the south develops a thermal stratification before the north (Koutsikopoulos et al., 1998; Castaing et al., 1999; Puillat et al., 2004). However, the general trend is that seasonal variations in physical factors such as temperature (Koutsikopoulos et al., 1998) and salinity (Puillat et al., 2004) in the region are greater than inter-annual variations.

Examining the vertical structure at each station reinforces this interpretation. The photic zones at all five stations are affected by freshwater runoff, with surface salinities $<34.5$. The temperature profiles show a seasonal progression from late winter to late spring (Biomet3N-Biomet3S, PEL-A-PEL-B, and Biomet1), with a net warming of the surface layer starting in spring. The shelf ecology shows a strong variability in time that is equivalent offshore of the two river plumes because it is related to general temperate-zone climatic fluctuations (Castaing et al., 1999). Therefore, the comparison of the five systems according to the seasons rather than to their geographical positions is appropriate for our purpose.

\subsection{Confidence on the inverse calculations}

In spite of the heterogeneity of the data and uncertain model assumptions, the conclusion of the two sensitivity analyses was that the inverse solutions clearly separated models with different flow structures. In fact, we observed variations 
for each carbon flow (Online supplement), but their intervals do not overlap from one system to another. The five systems remained well separated. In the five systems, phytoplankton and bacteria turnover times were directly coming from the productions and biomasses measured during the cruises. The measured turnover times of pico- and microphytoplankton in Biomet3N and Biomet3S seemed high (10 days for the picophytoplankton in Biomet3S, Table 3). But the sensitivity analysis showed us that changing the measured primary production values (i.e. approaching a more realistic turnover time) did not alter the properties of the system.

Legendre and Michaud (1998) developed different empirical estimates of the turnover time of biogenic carbon in marine pelagic organisms. Those parameters, such as the minimum turnover time, provide objective criteria to place organisms within functional groups. In our five systems, the protozoa and mesozooplankton turnover times were calculated with the value of biomass measured in the field and the value of production resulting from the inverse analysis calculations. The estimated turnover times of carbon in the protozoan compartments were less than 3 days and were mostly greater than 3 days for the mesozooplankton. This corresponds well with the separation of turnover times between protozoan, bacteria and phytoplankton on one hand ( $<3$ days) and mesozooplankton on the other ( $>3$ days) established by Legendre and Michaud (1998). This provides evidence that our flow estimates are reasonable.

\subsection{Hydrodynamics, phytoplankton production and food web functioning}

The goal of this study was to compare the planktonic food web dynamics that occur under the specific hydrodynamic conditions of the Bay of Biscay with the classical view of food web function in temperate oceans. In such environments, the transient hydrological conditions of the spring period (from mixed to stratified water column) correspond to the outburst of large phytoplankton cells (basis of the grazing food chain) whereas the strongly stratified conditions of the summer period correspond to the installation of a microbial food web (Cushing, 1989; Legendre and Rassoulzadegan, 1996). In the continental shelf of the Bay of Biscay, the occurrence of late winter blooms leads to a rapid limitation of the spring diatom blooms replaced by the development of small phytoplankton cells (Herbland et al., 1998; Labry et al., 2001; Labry et al., 2002). The characteristic food web dynamics could then differ from the conventional scheme. Nevertheless, in our study, the internal dynamics of the planktonic food web clearly differed between late winter, spring and late spring.

The two spring situations (PEL-A and B) corresponded to the establishment of the thermocline with highest temperature at the surface of the water column. They corresponded to transient conditions between the presence of the halocline resulting from late winter river runoff and the heating of the surface layer by spring solar radiations. The food webs functioned mainly as a grazing food chain (LeFevre et al., 1998; Sautour et al., 2000). The amount of primary production was high (more than
$1000 \mathrm{mg} \mathrm{C} \mathrm{m}^{-2} \mathrm{~d}^{-1}$ ) compared to the other models. But these values seemed low compared to other temperate Atlantic waters such as on the shelf of the Gulf of Cadiz (up to $4500 \mathrm{mg} \mathrm{C} \mathrm{m}^{-2} \mathrm{~d}^{-1}$; Huertas et al., 2006). However, since this latter area is very productive (Huertas et al., 2006), we may admit that our values are representative of the spring bloom in the Bay of Biscay as they were relatively close to other production estimates (up to $1500 \mathrm{mg} \mathrm{C} \mathrm{m}^{-2} \mathrm{~d}^{-1}$ ) found in May off the Gironde river plume (Laborde et al., 1999). Primary production was much higher than bacterial production with a bacterial to primary production ratio between 0.03 and 0.04 . In other coastal areas, such as in an upwelling station off A Coruña (Spain) in March or in the Gulf of St. Lawrence in late winter-early spring, this ratio was also very low at, respectively, 0.04 (Teira et al., 2003) and 0.03 (Savenkoff et al., 2000). Moreover, despite the relatively small sizes of phytoplankton, the two zooplankton compartments were mainly herbivorous and recycling activity was low (low FCI).

On the contrary, the post-spring situation (Biomet1) corresponded to stable hydrological conditions with a strong thermocline and the remainder of the winter halocline. A post-spring bloom situation may be characterized by the development of a microbial food web (Rivkin et al., 1996; Odate and Imai, 2003), typically induced by a shift in nutrient availability (Lochte et al., 1997). Primary production then is low and dominated by pico- and nano-phytoplankton (Azam et al., 1983; Sommaruga, 1995; Calbet and Landry, 2004). In our late spring situation, total primary production was low $\left(575 \mathrm{mg} \mathrm{C} \mathrm{m}^{-2} \mathrm{~d}^{-1}\right)$ and this value was similar to the one found in summer, for example, in the northern Baltic Sea where total primary production was up to $370 \mathrm{mg} \mathrm{C} \mathrm{m}^{-2} \mathrm{~d}^{-1}$ (Uitto et al., 1997). The high FCI as well as the low herbivory to detritivory ratio was an indicator of the preponderance of heterotrophic processes (Priddle et al., 1995), indicating that a large part of the carbon consumed came from regeneration via grazing on bacteria. This food web was based on regenerated production (Artigas, 1998; Herbland et al., 1998) and protozoa grazing was substantially greater than mesozooplankton grazing. This situation also occurred in summer in the Baltic Sea where the ingestion rates of heterotrophic nanoflagellates and ciliates were most of the time two times higher than the grazing rates of mesozooplankton (Uitto et al., 1997). The characteristics of the late spring situation (Biomet1) were then typical for stratified water column conditions and microbial pathways dominated this food web.

Microbial food webs are encountered in environment characterized by steady hydrodynamics (Legendre and Rassoulzadegan, 1996) such as, in temperate oceans, summer conditions with strongly stratified waters (Biomet1) and winter conditions with mixed waters. In late winter (Biomet3S and Biomet3N), the levels of primary and bacterial production, the high activity of protozoa compared to mesozooplankton and the high FCI index were similar to the post-spring bloom situation (Biomet1) when the microbial food web was dominant. However, the proportion of carbon lost by respiration was not as elevated as in Biomet1 and the loss by sedimentation was 


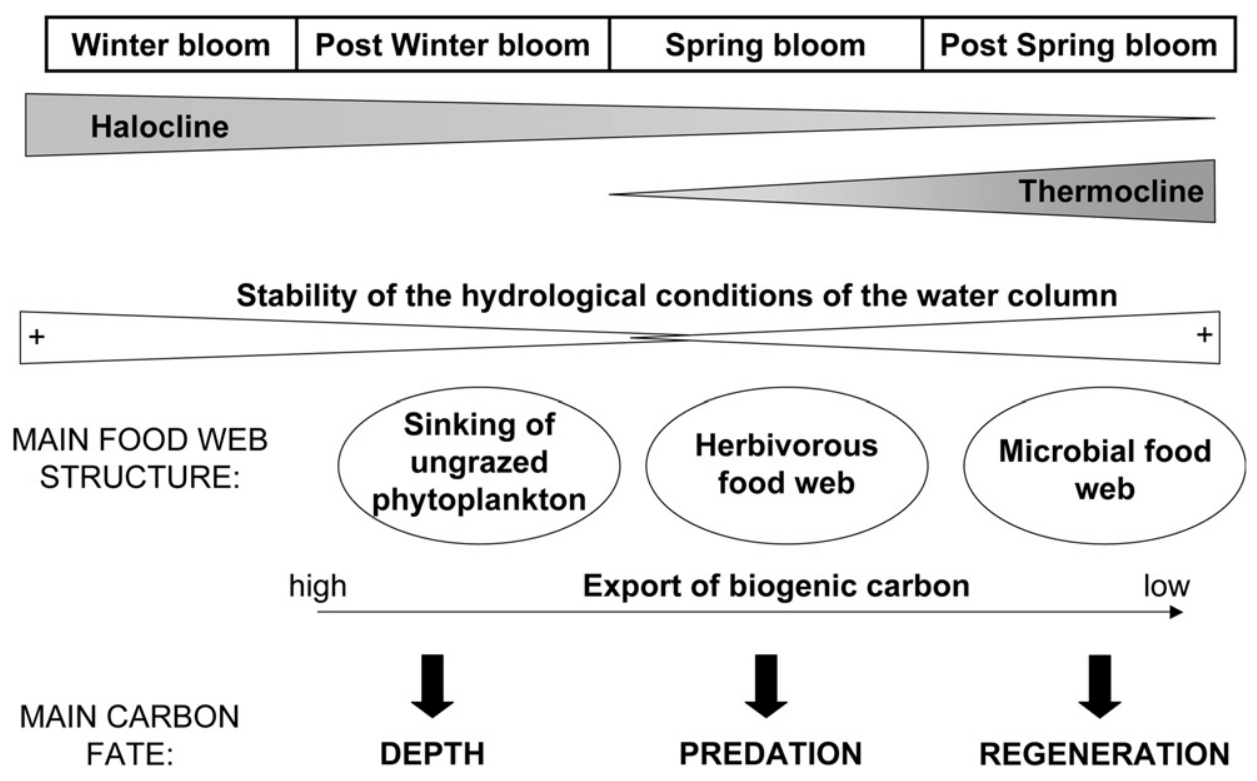

Fig. 8. Schematic synthesis of the results with emphasis on carbon fate in absolute terms.

the highest of the three seasons. The high sedimentation rate was mainly due to the downward flows of microphytoplankton material (55 and $36 \%$ of total detritus production made up by large phytoplankton) as it is usually observed after a strong bloom of diatoms in the absence of grazers (e.g. Savidge et al., 1992; Valiela, 1995). Legendre and Rassoulzadegan (1996) described this specific situation as corresponding to a rapid stabilization of the water column after a long period of mixing. In the Bay of Biscay, the water column is stratified by the river runoff at the end of the winter and the winter bloom is enhanced by brief and favorable anticyclonic atmospheric conditions (i.e. high luminosity) (Labry et al., 2001). The bloom is not accompanied by the development of large grazers (mesozooplankton) because of its short duration (Legendre and Rassoulzadegan, 1996). Thus, the late winter food web showed characteristics of microbial food web dominance and at the same time important sinking of phytoplankton.

\subsection{Assessment of carbon availability to plankton predators}

Despite the specific hydrological conditions of the continental shelf of the Bay of Biscay and the occurrence of winter microphytoplankton blooms, the dynamics of the planktonic food web seem to correspond to the characteristics typical of temperate oceans (Cushing, 1989) and to follow the continuum described by Legendre and Rassoulzadegan (1996) from high absolute carbon export to depth to carbon recycling within the food web (Fig. 8). Thus, the small size of phytoplankton cells in spring did not alter the herbivorous characteristics of the food web as had been anticipated by Herbland et al. (1998).

Considering the absolute values of carbon export flows, the three seasons showed three main carbon fates out of the planktonic food web (Fig. 8). When phytoplankton production is high and predator biomass too low (winter post-bloom), carbon is exported from the photic zone by sedimentation (Biomet3N and Biomet3S). During the spring bloom, new produced carbon is available to predators because planktonic grazers are present within the system (PEL-A and PEL-B). Finally, during a post-spring bloom period in the Bay of Biscay, carbon is largely regenerated and mainly lost by respiration. The flow of carbon available for plankton predators is low.

However, this scheme (Fig. 8) may be revised when considering carbon export flows in relation to primary production (Fig. 7). The proportion of the primary production available to plankton predators varies little from late winter to late spring. While the loss by sedimentation and respiration showed differences among systems that amount to $24 \%$ of the gross primary production, the loss by predation on mesozooplankton showed a maximal difference among systems of $4 \%$ of the primary production. The differences are sensitive (according to the sensitivity analysis) but they are very low compared to what it would be expected from the continuum of Legendre and Rassoulzadegan (1996). The capacity of planktonic food web to export carbon of the primary production to plankton predators then does not seem strongly related to the size structure of the phytoplankton. Rivkin et al. (1996) have already described this phenomenon with food webs of phytoplankton bloom and post-bloom situations in the Gulf of St. Lawrence. In our study, there is also some evidence of an inverse relation between bacterial to primary production ratios and the proportion of carbon available to predation (i.e. late winter and late spring situation), suggesting that bacterial activity may be a stronger determinant of export flows than phytoplankton size structure.

\section{Acknowledgements}

This research was supported by the French "Programme National Environnement Côtier" - Bay of Biscay working 
site. The authors thank all the persons who participated in the acquisition of the data. G.A. Jackson (Texas A\&M University, USA) and the two anonymous referees are acknowledged for their constructive comments on the form and the content of the manuscript.

\section{Appendix A. Supplementary data}

Supplementary data associated with this article can be found, in the online version, at doi:10.1016/j.ecss.2007. 01.003 .

\section{References}

Artigas, L.F., 1998. Seasonal variability in microplanktonic biomasses in the Gironde dilution plume (Bay of Biscay): relative importance of bacteria. Oceanologica Acta 21, 563-580.

Azam, F., Fenchel, T., Field, J.G., Gray, J.S., Meyer-Reil, L.A., Thingstad, F., 1983. The ecological role of water-column microbes in the sea. Marine Ecology Progress Series 10, 257-263.

Baretta-Bekker, J.G., Baretta, J.W., Koch Rasmussen, E., 1995. The microbial food web in the European Regional Seas Ecosystem Model. Netherlands Journal of Sea Research 33, 363-379.

Breed, G.A., Jackson, G.A., Richardson, T.L., 2004. Sedimentation, carbon export, and food web structure in the Mississipi River plume described by inverse analysis. Marine Ecology Progress Series 278, 35-51.

Bury, S.J., Boyd, P.W., Preston, T., Savidge, G., Owens, N.J.P., 2001. Sizefractionated primary production and nitrogen uptake during a North Atlantic phytoplankton bloom: implications for carbon export estimates. Deep Sea Research Part I: Oceanographic Research Papers 48, 689-720.

Calbet, A., Landry, M.R., 2004. Phytoplankton growth, microzooplankton grazing, and carbon cycling in marine systems. Limnology and Oceanography $49,51-57$

Caron, D.A., 1983. Technique for enumeration of heterotrophic and phototrophic nanoplankton, using epifluorescence microscopy, and comparison with other procedures. Applied and Environmental Microbiology 46, 491-498.

Castaing, P., Froidefond, J.M., Lazure, P., Weber, O., Prud'homme, R., Jouanneau, J.M., 1999. Relationship between hydrology and seasonal distribution of suspended sediments on the continental shelf of the Bay of Biscay. Deep Sea Research Part II: Topical Studies in Oceanography 46, 1979-2001.

Cushing, D.H., 1989. A difference in structure between ecosystems in strongly stratified waters and in those that are only weakly stratified. Journal of Plankton Research 11, 1-13.

Donali, E., Olli, K., Heiskanen, A.-S., Andersen, T., 1999. Carbon flow patterns in the planktonic food web of the Gulf of Riga, the Baltic Sea: a reconstruction by the inverse method. Journal of Marine Systems 23, 251-268.

Ducklow, H.W., Carlson, C.A., 1992. Oceanic bacterial production. Advances in Microbial Ecology 12, 113-181.

Dupuy, C., Le Gall, S., Hartmann, H.J., Bréret, M., 1999. Retention of ciliates and flagellates by the oyster Crassostrea gigas in French Atlantic coastal ponds: protists as a trophic link between bacterioplankton and benthic suspension-feeders. Marine Ecology Progress Series 177, 165-175.

Finn, J., 1976. Measures of ecosystem structure and function derived from analysis flows. Journal of Theoretical Biology 56, 363-380.

Fuhrman, J., Azam, F., 1982. Thymidine incorporation as a measure of heterotrophic bacterioplankton production in marine surface waters: evaluation and field results. Marine Biology 66, 109-120.

Gohin, F., Lampert, L., Guillaud, J.-F., Herbland, A., Nezan, E., 2003. Satellite and in situ observations of a late winter phytoplankton bloom, in the northern Bay of Biscay. Continental Shelf Research 23, 1117-1141.

Gohin, F., Loyer, S., Lunven, M., Labry, C., Froidefond, J.-M., Delmas, D., Huret, M., Herbland, A., 2005. Satellite-derived parameters for biological modelling in coastal waters: illustration over the eastern continental shelf of the Bay of Biscay. Remote Sensing of Environment 95, 29-46.

Haas, L.W., 1982. Improved epifluorescence microscopy for observing planktonic microorganisms. Annales de l'Institut Océanographique 58, 261-266.

Herbland, A., Delmas, D., Laborde, P., Sautour, B., Artigas, F., 1998. Phytoplankton spring bloom of the Gironde plume waters in the Bay of Biscay: early phosphorus limitation and food-web consequences. Oceanologica Acta 21, 279-291.

Huertas, I.E., Navarro, G., Rodriguez-Gàlvez, S., Lubiàan, L.M., 2006. Temporal patterns of carbon dioxide in relation to hydrological conditions and primary production in the northeastern shelf of the Gulf of Cadiz (SW spain). Deep Sea Research Part II: Topical Studies in Oceanography 53 , $1344-1362$.

Jackson, G.A., Eldridge, P.M., 1992. Food web analysis of a planktonic system off Southern California. Progress in Oceanography 30, 223-251.

Koutsikopoulos, C., Beillois, P., Leroy, C., Taillefer, F., 1998. Temporal trends and spatial structures of the sea surface temperature in the Bay of Biscay. Oceanologica Acta 21, 335-344.

Laborde, P., Urrutia, J., Valencia, V., 1999. Seasonal variability of primary production in the Cap-Ferret Canyon area (Bay of Biscay) during the ECOFER cruises. Deep Sea Research Part II: Topical Studies in Oceanography 46, 2057-2079.

Labry, C., Herbland, A., Delmas, D., Laborde, P., Lazure, P., Froidefond, J.M., Jegou, A.M., Sautour, B., 2001. Initiation of winter phytoplankton blooms within the Gironde plume waters in the Bay of Biscay. Marine Ecology Progress Series 212, 117-130.

Labry, C., Herbland, A., Delmas, D., 2002. The role of phosphorus on planktonic production of the Gironde plume waters in the Bay of Biscay. Journal of Plankton Research 24, 97-117.

Labry, C., Delmas, D., Herbland, A., 2005. Phytoplankton and bacterial alkaline phosphatase activities in relation to phosphate and DOP availability within the Gironde plume waters (Bay of Biscay). Journal of Experimental Marine Biology and Ecology 318, 213-225.

Landry, M.R., Hassett, R.P., 1982. Estimating the grazing impact of marine microzooplankton. Marine Biology 67, 283-288.

Lazure, P., Jegou, A.-M., 1998. 3D modelling of seasonal evolution of Loire and Gironde plumes on Biscay Bay continental shelf. Oceanologica Acta $21,165-177$.

Leakey, R.J.G., Burkill, P.H., Sleigh, M.A., 1994. A comparison of fixatives for the estimation of abundance and biovolume of marine planktonic ciliate populations. Journal of Plankton Research 16, 375-389.

LeFevre, J., Legendre, L., Rivkin, R.B., 1998. Fluxes of biogenic carbon in the Southern Ocean: roles of large microphagous zooplankton. Journal of Marine Systems 17, 325-345.

Legendre, L., Rassoulzadegan, F., 1995. Plankton and nutrients dynamics in marine waters. Ophelia 41, 153-172.

Legendre, L., Rassoulzadegan, F., 1996. Food-web mediated export of biogenic carbon in oceans: hydrodynamic control. Marine Ecology Progress Series 145, 179-193.

Legendre, L., Michaud, J., 1998. Flux of biogenic carbon in oceans: sizedependent regulation by pelagic food webs. Marine Ecology Progress Series $164,1-11$.

Lochte, K., Bjornsen, P., Giesenhagen, H., Weber, A., 1997. Bacterial standing stock and production and their relation to phytoplankton in the Southern Ocean. Deep Sea Research 44, 321-340.

Loyer, S., Lampert, L., Menesguen, A., Cann, P., Labasque, T., 2006. Seasonal evolution of the nutrient pattern on Biscay Bay continental shelf over the years 1999-2000. Scientia Marina 70, 31-46.

Niquil, N., Jackson, G.A., Legendre, L., Delesalle, B., 1998. Inverse model analysis of the planktonic food web of Takapoto Atoll (French Polynesia). Marine Ecology Progress Series 165, 17-29.

Niquil, N., Arias-Gonzalez, J.E., Delesalle, B., Ulanowicz, R.E., 1999. Characterization of the planktonic food web of Takapoto Atoll lagoon, using network analysis. Oecologia 118, 232-241.

Niquil, N., Pouvreau, S., Sakka, A., Legendre, L., Addessi, L., Le Borgne, R., Charpy, L., Delesalle, B., 2001. Trophic web and carrying capacity in a pearl oyster farming lagoon (Takapoto, French Polynesia). Aquatic Living Resources 14, 165-174. 
Odate, T., Imai, K., 2003. Seasonal variation in chlorophyll-specific growth and microzooplankton grazing of phytoplankton in Japanese coastal water. Journal of Plankton Research 25, 1497-1505.

Porter, K.G., Feig, Y.S., 1980. The use of DAPI for identifying and counting aquatic microflora. Limnology and Oceanography 25, 943-948.

Priddle, J., Leakey, R., Symon, C., Whitehouse, M., Robins, D., Cripps, G., Murphy, E., Owens, N.J.P., 1995. Nutrient cycling by Antarctic marine microbial plankton. Marine Ecology Progress Series 116, 181-198.

Puillat, I., Lazure, P., Jegou, A.M., Lampert, L., Miller, P.I., 2004. Hydrographical variability on the French continental shelf in the Bay of Biscay, during the 1990s. Continental Shelf Research 24, 1143-1163.

Putt, M., Stoecker, D.K., 1989. An experimentally determined carbon: volume ratio for marine "oligotrichous" ciliates from estuarine and coastal waters. Limnology and Oceanography 34, 1097-1103.

Rat'kova, T.N., Wassmann, P., 2002. Seasonal variation and spatial distribution of phyto- and protozooplankton in the central Barents Sea. Journal of Marine Systems 38, 47-75.

Richardson, T.L., Daniels, R.M., 2003. Carbon cycling through planktonic food webs: using inverse analysis to synthesize U.S. JGOFS data. U.S. JGOFS Newsletter 12, 5-6.

Richardson, T.L., Jackson, G.A., Burd, A.B., 2003. Planktonic food web dynamics in two contrasting regions of Florida Bay. U.S. Bulletin of Marine Science 73, 569-591.

Rivkin, R.B., Legendre, L., Deibel, D., Tremblay, J.-E., Klein, B., Crocker, K., Roy, S., Silverberg, N., Lovejoy, C., Mesplé, F., Romero, N., Anderson, M.R., Mattews, P., Savenkoff, C., Vézina, A., Theriault, J.-C., Wesson, J., Bérubé, C., Ingram, R.G., 1996. Vertical flux of biogenic carbon in the ocean: is there food web control? Science 272, 1163-1166.

Sakshaug, E., Bricaud, A., Dandonneau, Y., Falkowski, P.G., Kiefer, D.A., Legendre, L., Morel, A., Parslow, J., Takahashi, M., 1997. Parameters of photosynthesis: definitions, theory and interpretation of results. Journal of Plankton Research 19, 1637-1670.

Sautour, B., Artigas, L.F., Delmas, D., Herbland, A., Laborde, P., 2000. Grazing impact of micro-mesozooplankton during a spring situation in coastal waters off the Gironde estuary. Journal of Plankton Research 22, 531-552.

Savenkoff, C., Vezina, A.F., Roy, S., Klein, B., Lovejoy, C., Therriault, J.-C., Legendre, L., Rivkin, R., Berube, C., Tremblay, J.-E., Silverberg, N., 2000. Export of biogenic carbon and structure and dynamics of the pelagic food web in the Gulf of St. Lawrence. Part 2. Inverse analysis. Deep Sea Research Part II: Topical Studies in Oceanography 47, 609-635.

Savidge, G., Turner, D.R., Burkill, P.H., Watson, A.J., Angel, M.V., Pingree, R.D., Leach, H., Richards, K.J., 1992. The BOFS 1990 spring bloom experiment: temporal evolution and spatial variability of the hydrographic field. Progress in Oceanography 29, 235-281.

Sherr, E., Sherr, B.F., Paffenhofer, G.-A., 1986. Phagotrophic protozoa as food for metazoans: a "missing" trophic link in marine pelagic food webs? Marine Microbial Food Webs 1, 61-80.
Sherr, E.B., Caron, D.A., Sherr, B.F., 1994. Staining of heterotrophic protists for visualisation via epifluorescence microscopy. In: Kemp, P.F., Sherr, B.F., Sherr, E.B., Coll, J.J. (Eds.), Handbook of Methods in Aquatic Microbial Ecology. Lewis Publishers, Boca Raton, pp. 213-227.

Sommaruga, R., 1995. Microbial and classical food webs: a visit to a hypertrophic lake. FEMS Microbiology Ecology 17, 257-270.

Teira, E., Albade, J., Alvarez-Ossorio, M., Bode, A., Carino, C., Cid, A., Fernandez, E., Gonzalez, N., Lorenzo, J., Valencia, J., Varela, M., 2003. Plankton carbon budget in a coastal wind-driven upwelling station off a Coruna (NW Iberian Peninsula). Marine Ecology Progress Series 265, $31-43$.

Thingstad, T.F., Rassoulzadegan, F., 1999. Conceptual models for the biogeochemical role of the photic zone microbial food web, with particular reference to the Mediterranean Sea. Progress in Oceanography 44, 271-286.

Uitto, A., Heiskanen, A.-S., Lignell, R., Autio, R., Pajuniemi, R., 1997. Summer dynamics of the coastal planktonic food web in the northern Baltic Sea. Marine Ecology Progress Series 151, 27-41.

Ulanowicz, R.E., 1986. Growth and Development. Springer-Verlag, New York, $203 \mathrm{pp}$.

Ulanowicz, R.E., 1999. NETWRK 4.2: a package of computer algorithms to analyse ecological flow networks. www.glerl.noaa.gov/EcoNetwrk/.

Valiela, I., 1995. Marine Ecological Processes. Springer-Verlag, New York, $686 \mathrm{pp}$.

Vincent, D., Hartmann, H.J., 2001. Contribution of ciliated microprotozoans and dinoflagellates to the diet of three copepod species in the Bay of Biscay. Hydrobiologia 443, 193-204.

Vézina, A., Platt, T., 1988. Food web dynamics in the ocean. 1. Best-estimates of flow networks using inverse methods. Marine Ecology Progress Series 42, 269-287.

Vézina, A., 1989. Construction of flow networks using inverse methods. In: Wulff, F.F., Field, J.G., Mann, K.H. (Eds.), Network Analysis in Marine Ecology. Springer-Verlag, Berlin, pp. 62-81.

Vézina, A.F., Pace, M.L., 1994. An inverse model analysis of planktonic food webs in experimental lakes. Canadian Journal Fishery and Aquatic Sciences 51, 2034-2044.

Vézina, A.F., Savenkoff, C., 1999. Inverse modeling of carbon and nitrogen flows in the pelagic food web of the northeast subarctic Pacific. Deep Sea Research Part II: Topical Studies in Oceanography 46, 2909-2939.

Vézina, A.F., Savenkoff, C., Roy, S., Klein, B., Rivkin, R., Therriault, J.-C., Legendre, L., 2000. Export of biogenic carbon and structure and dynamics of the pelagic food web in the Gulf of St. Lawrence. Part 1. Seasonal variations. Deep Sea Research Part II: Topical Studies in Oceanography 47, 585-607.

Vézina, A.F., Pahlow, M., 2003. Reconstruction of ecosystem flows using inverse methods: how well do they work? Journal of Marine Systems 40-41, 55-77. 